\title{
APPROACHES TO STATUTORY INTERPRETATION AND LEGISLATIVE HISTORY IN FRANCE
}

\author{
Claire M. GERMAIN*
}

\section{INTRODUCTION}

In France, Justice Jackson's question about where to look for the meaning of a statute would be phrased in broader terms and would not be limited to the question of whether to look only at the words of a statute or also at the legislative intent. French law starts from the premise that statutes and codes are the foundations of the legal system in the same way that cases are the foundation of the common-law system. Because of the primacy of written law in France, statutory interpretation lies at the heart of French law. Statutory interpretation is very flexible, and there are no strict canons of interpretation. ${ }^{1}$ The drafters of the Civil Code, Napoléon ${ }^{2}$ in particular, intended only to set general principles, ${ }^{3}$ leaving it up to judges to apply the principles to the circumstances of cases. ${ }^{4}$ This is why the Civil Code of 1804 can

Copyright (C) 2003 by Claire M. Germain.

* Professor of Law and Edward Cornell Law Librarian, Cornell University. Many thanks to Marcel Safar, Cornell Law School JD/Maitrise-en-droit '04, for his research assistance and insightful browsing of the collection of the Cornell Law Library.

1. RENÉ DAVID, FRENCH LAW 166 (Michael Kindred trans., Louisiana State University Press 1972)(1959).

2. Bonaparte at the time. The 1804 original code was called the Code civil des français. In 1807, it became Code Napoléon, with references to the Emperor and the Empire. See H. Mazeaud, J. Mazaud \& François Chabas, LeÇOns De Droit Civil, t. 1 (12th ed. 2000) 81.

3. It is, however, important to note that these general principles were not philosophical considerations but were based on existing rules and customs, whether old or recent. The four drafters were practitioners who pressed by time, picked the best, rather than coming up with a scientific and original creation. Bonaparte was an active participant in the discussions. Id. at 82 .

4. Id. at 43, 82. According to Portalis, one of the four drafters of the Civil Code, "the function of statute is to establish through a broad view the general maxims of the law; to establish principles rich in consequences and not to descend into the detail of questions, which could arise on every question. It is up to the judge and the jurist imbued with the general spirit of the laws, to direct their application." JOHN BELL, FRENCH LEGAL CULTURES 72 (2001) quoting original French text in Discours PRÉLIMINAIRE in NAISSANCE DU CODE CIVIL 41 (F. EWALD ed. 1989). 
still resolve many of today's issues, such as those generated by automobile traffic accidents, that could not be anticipated at the time of writing. ${ }^{5}$ It is commonly understood that legislators cannot anticipate all situations and all difficulties that might arise from the application of legal texts. ${ }^{6}$ The meaning of statutes is not always clear. Moreover, the adaptation of texts to concrete situations may cause difficulties. Interpretation is needed on the meaning and scope of the text. ${ }^{7}$

\section{JUDICIAL INTERPRETATION AND THE CIVIL CODE}

In France, a judge has both the power and the obligation to interpret statutes on the basis of Article 4 of the Civil Code, which states that a judge who refuses to come to a judgment, under pretext of the silence, obscurity, or insufficiency of the law, may be prosecuted on the basis of a denial of justice. The judge's power, however, is limited to decisions concerning specific instances. Article 5 of the Civil Code stipulates that judges are prohibited from pronouncing, by way of a general, law-making provision, on matters submitted to them (called an arrêt de règlement). ${ }^{9}$ This peculiarity, an essential difference from the common law, is historical. It results from the revolutionaries' hostility toward judges in the Parliaments, who, before the French Revolution, issued general rulings and fought all attempts at reform by the King. ${ }^{10}$

A corollary principle is that the judge must give reasons for ( $\mathrm{mo}$ tiver) a decision on the basis of a text. ${ }^{11}$ Thus, almost all cases are based on statutes. When the statute is clear, it must be applied, but, many times, there is also a need for interpretation.

French codes contain no provisions regarding methods of interpretation. $^{12}$ It has therefore been up to judges to find ways to inter-

5. MAZEAUd, MAZAUd \& ChABAS, supra note 2, at 82 .

6. As a comparison, the German Civil Code, which tried to anticipate all situations, is deemed to have failed in that regard. See id. at 107.

7. Id. at 82 .

8. Code Civil [C. Civ.] art. 4 (Fr.), reprinted in George A. Bermann ET. AL., French LAW 4-10 (1998).

9. MAZEAUD, MAZAUD \& CHABAS, supra note 2, at 178.

10. Id.

11. Id. at 183 .

12. More modern civil-law codes contain such provisions. A particularly interesting example is the Civil Code of Louisiana of 1870, which provides extensive rules of interpretation in articles 13 to 21, finishing in Art. 21 with the statement that "[I]n all civil matters, where there is no express law, the judge is bound to proceed and decide according to equity. To decide equitably, an appeal is to be made to natural law and reason, or received usages, where positive law is silent." La. Civ. Code. arts. 13-21. A provision similar to art. 21 was in the draft French Civil 
pret statutes, and to scholarly commentators to expound on the various methods. The major methods of interpretation under different classifications are exegetic and teleological, according to French scholarship. $^{13}$ The exegetic method makes use of legislative history. The teleological method, which looks at the social objective of the statute, has several different variations. The use of legislative history-travaux préparatoires - has consistently been considered one of the major ways to interpret a statute, but its use has varied depending on the age of the law, as described below. It coexists with other methods of interpretation.

In the system originally adopted in the Constitution of 1791, judges referred questions of interpretation to the legislature, which resolved differences among courts. This process, called référé législatif, ceased in $1837^{14}$ because of the danger of decisions inspired by political considerations and the lack of necessary independence to resolve already-existing disputes. ${ }^{15}$ Parliament can interpret its own laws by issuing a posterior law, called an interpretive law. Courts are

Code, supported by Portalis, but then dropped. SiR William DALE, Legislative DRAFTing: A New Approach 293 (1977). See also Alfred Rieg, Rapport Français sur le droit civil, in 29 Travaux de L'association Henri Capitant 70, 71 (1978).

13. Legal scholarship, termed la doctrine in France, consists of books, articles in academic and other journals, and case notes. These writings collect the various solutions reached by judicial practice or custom, group them systematically, relate them to general theories or ideas, and demonstrate their systematic interdependence. See Charles Szladits \& Claire M. GERMAin, Guide To Foreign LEgal MATERIALS: FrenCH (2d ed. 1985). Renewed interest in legal studies followed the promulgation of the Code Civil. The re-established law schools commented upon the new Code Civil. The first treatises were commentaries on the Code, article by article; subsequent treatises examined the provisions of the Code by subject matter. For a good history of commentators of the Code Civil, see J. CHARMONT \& A. CHAUSSE, Les interprètes du Code civil, in LE CODE CIVIL, 1804-1904, 1 LE LIVRE DU CENTENAIRE 131 (1904). Legal scholarship also systematizes case law. French writers have a long tradition of critiquing court decisions, particularly in case notes (commentaires d'arrêt), written since the middle of the $19^{\text {th }}$ century. For a good article retracing the history of commentators on cases since the enactment of the Code civil, see E. MEYNIAL, Les recueils d'arrêts et les arrêtistes, in LE CODE CIVIL, 1804-1904, 1 LE LIVRE DU CENTENAIRE 173 (1903). Meynial demonstrates the importance of case law and the care with which court decisions have been looked at and scrutinized, as well as the influence of these case commentaries on the practice of law, later court decisions, and other scholarly writings. Meynial also underlines the influence of case law on modifying the codes. Ledru-Rollin, lawyer at the Cour de cassation, and editor in chief of the Journal du Palais, writes that case law "has arisen from the law, little by little, impresses itself with equity, reflects the morals (or customs, moeurs), the ideas, and new discoveries, and from submissive slave, proclaims itself queen in turn." Id. at 186.

14. Rieg, supra note 12 , at 71.

15. MAZEAUD, MAZAUD \& CHABAS, supra note 2, at 167. 
very reluctant to apply such laws retroactively. ${ }^{16}$ In practice, these laws are rare and do not play a significant role. ${ }^{17}$

As a method of statutory interpretation, the exegetical school triumphed in the nineteenth century. In the exegetical school of thought, as characterized in the doctrinal writings and commentaries, a careful study of the text should be sufficient to reveal the solution to any case. ${ }^{18}$ The aftermath of the writing of the Napoleonic codes led to the notion that the law was complete in itself. The entire law was deemed to be contained in the codes, ${ }^{19}$ and interpretation was centered on the texts. Logical reasoning methods, such as reasoning by analogy, were used to resolve difficulties encountered in the practice of applying the code. If the text was silent, one could use the rule of a similar case; reasoning a contrario, giving a result opposite to the rule of the text; reasoning by induction, using the rules given in other cases; and reasoning by deduction, starting from the principle set by the legislator, and expanding it to other situations. ${ }^{20}$ The exegetic method emphasizes respect for the will of the legislator. If the law is clear, a judge must apply it without interpretation. If the law is obscure, a judge will examine the travaux préparatoires to discover the intention of the legislature, and, in the clear thinking of the legislature, the meaning of obscure provisions. ${ }^{21}$

By the end of the nineteenth century, doctrinal writers observed that the courts were less likely to observe a literal interpretation of a law than to construct an equitable interpretation of the legal texts. ${ }^{22}$ Some of the code provisions had become obsolete, and the industrial revolution, as well as economic, political, and other societal changes had occurred. In a famous work, François Gény proposed a new method of interpretation, the school of free scientific research. ${ }^{23}$ The thesis was as follows: why worry about consulting legislative history to

16. Id. at 151 .

17. Rieg, supra note 12 , at 71.

18. Andrew West et Al., The French Legal System, an introduction ( $2 \mathrm{~d}$ ed. 1998) (1992). For an excellent description of doctrinal writings and the names of the main authors, together with many bibliographical references, see MAZEAUD, MAZAUD \& CHABAS, supra note 2, at 171-176.

19. G. MARTy \& P. RAynaud, Introduction GÉnÉRALe À L'Étude du Droit 141 (2D ED. 1972).

20. Mazeaud, MaZaud \& Chabas, supra note 2, at 172; Alex Weill, Droit Civil, $185-186\left(4^{\text {th }}\right.$ ed.1979).

21. Id. at 172 .

22. Id.

23. FranÇOIS GÉNY, 1 MÉthode D'INTERPRÉtATION ET SOURCES DU DROIT PRIVÉ FRANÇAIS (2d ed. 1919). 
track the will of a legislator who is gone? Faced with an obscurity or gap in the law, a judge must become a legislator and be concerned about social needs, the ideals of the moment, comparative law, plus history, which will show institutional evolution. Starting as an interpreter, the judge will become a legislator. ${ }^{24}$ This movement spread to other countries, such as Germany (Freies Recht). In Switzerland, thanks to the efforts of Professor E. Huber, it inspired the language in article 1 of the Swiss Civil Code of 1907, which expressly gives large powers to the judge when neither the law or custom resolve the question raised in the litigation. The judge should decide in accordance with the rule he would establish as a legislator. ${ }^{25}$

This philosophy effected a profound change in how courts considered statutes in civil law countries. However, French courts did not adopt it. Although French courts took liberties with texts, they did not openly free themselves from texts in the ways advocated by Gény. ${ }^{26}$

The historical evolution method is a type of teleological interpretation also known as softening of the texts (assouplissement des textes). A judge using this method looks only at the text, recognizing that researching the will of the legislature may be futile in the light of societal changes that have occurred since the law was enacted. This method considers social needs to be constantly evolving, and permits a judge freely to adapt the text to the social needs of the time, based on research as to what the thought of the legislature would be today. Gény opposed this approach. ${ }^{27}$

The social purpose method, advocated by Louis Josserand, identifies the social purpose or objective of the legislation. ${ }^{28}$

In 1935, a famous French law professor, Henri Capitant, wrote a piece against the use of legislative history in statutory interpretation, advocating the English position of not allowing it. Capitant argued that parliamentary discussions lead to the expression of personal views, rather than a general sense of the spirit of the law. ${ }^{29}$ His ideas

24. See id. See also JeAn Carbonnier, Droit Civil 177 (12 ${ }^{\text {th }}$ ed. 1979).

25. R. DAVID, 1 LE Droit FranÇAIS 145 (1960).

26. FranÇOIS TERrÉ, Droit CIVIL 387 ( $4^{\text {th }}$ ed. 1998).

27. M. COUdERC, LES TRAVAUX PRÉPARATOIRES DE LA LOI OU LA REMONTÉE DES ENFERS, D. 1975. Chr. 249, 251, citing FranÇOIS GÉNY, MÉTHODES D'INTERPRÉTATION ET SOURCES EN DROIT PRIVÉ POSITIF ( $2^{\text {nd }}$ ed. 1954) (1899).

28. E. STEINER, FRENCH LegAl METHOD (2002) 64. The book provides a very thorough analysis of French statutory interpretation.

29. HENRI CAPITANT, L'INTERPRÉTATION DES LOIS D'APRÈs LES TRAVAuX PRÉPARATOIRES, D.H. 1935, Chr.77. 
may have been influenced by political considerations and the legislative process of that particular time period of the Fourth Republic.

In the 1970s, a new period of legislative reform occurred in France. Large portions of the Napoleonic codes were replaced in civil law (guardianship, matrimonial regimes, parental authority, divorce) and in commercial law (corporation law, bankruptcy). In light of these changes, the exegetic method and use of legislative histories enjoyed a resurgence of interest. This exegetic method differs from its nineteenth-century counterpart. Broader modes of investigation into legislative intent include ministerial responses, ${ }^{30}$ as well as opinions of commissions and experts ${ }^{31}$ Statutory interpretation can also be done by the administration in the form of administrative circulars, for instance, in tax matters. Although the administration may issue circulars to subordinates, they do not have the effect of law over individuals or judges. ${ }^{32}$ The Cour de cassation frequently reminds judges that these circulars cannot bind judges as to the meaning and scope of the provisions they interpret. ${ }^{33}$ Nevertheless, practitioners and judges take them into account. Very often, parliamentarians submit written questions concerning the interpretation of a law to the ministers, whose responses are published in the Journal officiel. Their responses only expressed opinions, subject to the sovereign interpretation of the courts. ${ }^{34}$ More interesting is the process of requesting an opinion from the Cour de cassation. Since enactment of a 1991 law, judges of the lower courts may ask the highest court for advice on how it would rule on a request, before they themselves decide on a request which raises a new question of law presenting a serious difficulty. This opinion, not binding the court, does not constitute a prohibited arrêt de règlement. ${ }^{35}$ Finally, since 1969, the annual report of the Cour de cassation tells the legislature, which has taken it into consideration several times, about areas where it should intervene. ${ }^{36}$

French scholarly writers, whose tradition is to engage in the systematization of legal concepts, have used different classifications to describe various methods of statutory interpretation. Jean Carbonnier, for instance, describes three main methods of statutory interpre-

\footnotetext{
30. B. OPPETIT, LES RÉPONSES MINISTÈRIELLES, D. 1974, Chr. at 107.

31. TERRÉ, supra note 26 , at 475 .

32. MAZEAUD, MAZAUD \& CHABAS, supra note 2, at 167.

33. See Rieg, supra note 12, at 71.

34. MAZEAUd, MAZAUd \& ChaBAs, supra note 2, at 167.

35. See id. at 173 .

36. COUDERC, supra note 27 , at 249.
} 
tation as the exegetic method, the method of social purpose, and the free scientific research method. ${ }^{37}$ René David, in possibly the most lucid account, distinguishes among grammatical, logical, historical (including legislative history), and teleological interpretations. ${ }^{38} \mathrm{Al}-$ fred Rieg distinguishes between looking at the intention of the legislature, which is particularly appropriate for recent laws, and looking at the social purpose of the law, particularly for old laws. ${ }^{39}$ There is an abundant literature of doctrinal writings, which the judges may not even see. ${ }^{40}$

\section{WHAT DO JUDGES DO?}

What do judges do? Today, judges employ a variety of the methods of interpretation mentioned above. They sometimes boldly interpret certain texts, to the point of giving them a meaning opposite to the original provision. A famous example involved art. 1384 (1) which was interpreted to create civil liability for traffic accidents, on the basis that a thing-a chose-caused injury. ${ }^{41}$ Sometimes judges interpret a provision literally. They always attempt to maintain harmony between the legislation they apply and changing times and needs. Judges are accustomed to interpret the law and apply it to each separate instance. They take reasonable, equitable, moral, and social needs into account more than methods. Thus, Gény's works on methods of legal interpretation had no influence on the judicial interpretation because judges do not openly free themselves from the text. ${ }^{42}$

The current methods of statutory interpretation can be summarized as the following:

1. When a text is clear, it should be applied and not interpreted, unless an absurd result would follow.

37. CARBOnNIER, supra note 24, at 179. Carbonnier uses these classifications to describe both case law and doctrinal writings.

38. DAVID, supra note 25, at 140-46.

39. Rieg, supra note 12 , at $82-83$.

40. MARTY \& RAYNAUD, supra note 19 , at 246.

41. The most extensive commentary on this in English can be found in DAVID POLLARD, SOURCEBOOK ON FRENCH LAW 225-304 (2d ed. 1998).

42. MAZEAUd, MAZAUd \& CHABAS, supra note 2, at 182.

43. Id. In a famous case, the courts had to interpret a decree that forbade travelers to climb or get off a train when it was completely stopped. The text was clear, but the courts condemned travelers who climbed or got off before the train was stopped. Cass. crim. March 8 1930, D.P. 1930, 1, 101, note P. Voirin. See Rieg, supra note 12, at 74-78, for a good description of such instances, with examples of various instances when a text is not clear as it seems to be. 
2. When a text is ambiguous or obscure, courts look for the will of the legislature. For that, a judge first examines the text itself with care, and considers commentaries written about the text. This is not limited to the provision to be applied but includes the chapter or the entire law. Often a provision is obscure only if separated from its context. ${ }^{44}$

3. If this study is insufficient, courts often go to the travaux préparatoires to discover the legislature's thinking. The Cour de cassation agrees with this process, but also states that the travaux préparatoires never bind the court. René David, who calls this process the historical method of interpretation, cites its frequent use by the courts. ${ }^{45}$

4. When a text does not directly provide the solution for a dispute, judges need at least to start from a text to situate the rule that they will design. French judicial decisions almost always invoke a text, and it is exceptional for a court not to refer to a legal text. However, sometimes courts invoke general principles of law. $^{46}$

5. If the legislative history is confused, or the law is too old, the judge will look at other considerations and use what the scholarly writers call the teleological interpretation method. ${ }^{47}$ This approach is mostly used by the highest courts, the Cour de cassation and the Conseil d'Etat, rather than the lower courts. ${ }^{48}$

Thus, in general, courts today use the exegetic method and legislative history methods when the text is recent, but use the teleological approach when the text is old and the legislature has not expressed its thinking.

It is hard to find statistical evidence of whether legislative history is used to interpret statutes from the texts of decisions themselves. ${ }^{49}$ This is because French decisions, particularly those of the Cour de cassation, are succinct. Even though a court must give reasons for its decision, the decisions do not explain the policy decisions made and

\footnotetext{
44. MAZEAUd, MAZAUd \& ChABAs, supra note 2, at 182.

45. DAVID, supra note 25, at 143.

46. Id. at 186.

47. Id. at 143 .

48. Id. at 147 ; Rieg, supra note 12 , at 84 .

49. A study conducted on the online database Lexislaser of the Cour de cassation decisions between 1984 and 1992 reveals that few decisions refer to the travaux préparatoires. See Nicolas Molfessis, Le CONSEIL CONSTITUTIONNEl ET Le Droit PRIVÉ 1997, at 371, n. 2.
} 
the reasoning that led the judge(s) to arrive at a certain result. It is difficult to find the precise reasoning followed by the judge. It is often emphasized that French decisions do not state explicitly which process of interpretation has been used and why. ${ }^{50}$ For instance, why was one text interpreted restrictively, and another one more expansively $?^{51}$ This contrasts greatly with the decisions of common-law courts, where one can say that lawyers reading the decision know why it has been rendered. ${ }^{52}$

How then does one understand the policy reasons behind a decision? This is possible only by reading the recommendations (conclusions) of the judge appointed to represent the public interest, who writes a report on the case (Avocat général in Cour de cassation, and Commissaire du gouvernement, in Conseil d'Etat). These conclusions are sometimes published before the text of the case itself and the case notes, which accompany selected cases in the weekly law review publications. ${ }^{53}$

The use of legislative history is predicated on understanding precisely the rules regarding the elaboration of laws. ${ }^{54}$ The quality of the legislative materials is high in France, which may account for their use in interpretation. In France, most legislative bills originate with the government. ${ }^{55}$ Government bills are discussed in the Council of Ministers after consultation with the Conseil d'Etat, which consults with government officials and writes a report, to be discussed with the Conseil d'Etat. The government takes the Conseil d'Etat's advice into consideration (or not), and the bill is then filed with the office of one of the two houses. The Conseil d'Etat thus plays an important role in drafting legislation and advising the government. In Parliament, the

50. Rieg, supra note 12 , at 72.

51. Id. See also H. Battifol, Questions de l'interprétation juridique, 17 Archives De Philosophie du Droit 9 (1972).

52. Some French writers have argued for a more explicit articulation of judicial decisionmaking. See, e.g., Adolphe Touffait \& André Tunc, Pour une motivation plus explicite des décisions de justice, notamment celles de la Cour de cassation, 73 Revue Trimestrielle De Droit Civil 487 (1974). 34,87 .

53. On the role of case annotations, see generally SZLADITS \& GERMAIN, supra note 13 , at

54. COUDERC, supra note 27 , at 252.

55. Art. 39 of the 1958 Constitution. The Prime minister and members of Parliament have the right to introduce legislation. Jean Massot, Legislative Drafting in France: the Role of the Conseil d' Etat, 22 Statute Law Review 96 (2001). Massot explains that out of 100 Acts passed each year on the average by Parliament, 80-90 are government bills (projets de lois). Parliament's members can introduce legislative proposals (propositions de lois), but only if they do not have any budgetary impact. 
bill is sent to the National Assembly or the Senate and then assigned to one commission, with a Rapporteur who will issue a report. This report will be discussed during the oral debates. ${ }^{56}$

The documents of the legislative history of a law include:

1. the Government's statement of reasons for bill (exposé des motifs);

2. the reports of successive examinations, with amendments proposed and rejected, by the Parliamentary Committees in both the National Assembly and the Senate; and

3. the floor debates in the two houses.

The Rapporteur for the parliamentary commission to which the report is sent issues a report in two parts. The first is an examination of the text of the draft law, in its political and legal setting, with a detailed study of the proposals and motivation and views of members. The second includes a comparative table, showing the provisions of the existing law, the text proposed by the government, and any amendments proposed by the commission. The report is printed, published, and held by the members of the house when they debate the law. Interestingly, the Constitutional Court makes great use of travaux préparatoires. This is explained by the fact that this body looks upon the constitutionality of laws immediately before they are put into effect.

Historically, the use of the exegetic method in France in the nineteenth century was facilitated by the fact that there was good access to the legislative history of the five Napoleonic codes. The most comprehensive set for the Code Civil was published by Fenêt. ${ }^{57}$ The legislative history of subsequent laws was then published in the Journal officiel and distributed throughout France. The Journal officiel itself is divided into several sections, including one on Lois et décrets (Law and Decrees) that provides references to the documents of the legislative history of law, to be found in the other sections, Débats de l'Assemblée Nationale, Débats du Sénat, et Impressions (separate series where the parliamentary reports for each house are published).

Today, there is a great deal of interest in legislative histories from practitioners and citizens alike, even though scholarly writers do

56. The process and importance of various documents are well described in detail by SIR WILLIAM DALE, supra note 12, and by MiCHEL COUDERC, supra note 27, at 252.

57. Pierre-Antoine FenÊt, ReCUeIL COMPlet des travauX PrÉPARATOIRES DU CODE CIVIL (15 vols.) (1827). 
not always favor using them. It is also clear that the government makes special efforts to disseminate parliamentary documents, ${ }^{58}$ including simultaneous publication of documents and debates relative to a particular law; mention in the Journal Officiel of references to parliamentary works next to the publication of the particular law; issuance of compiled legislative histories of important laws by the general secretary of the National Assembly; and publication by the National Assembly and the Senate of a weekly bulletin of their work with cross-references to documents and debates, accompanied by short analyses of the legislative work. ${ }^{59}$

Many commentaries are written about any proposed legislative reform, mostly in law reviews. The commentaries are based primarily on the travaux préparatoires. ${ }^{60}$ In 1972, for instance, over half of the Chroniques of the Recueil Dalloz were devoted to commentaries or critiques of laws, the argumentation in which expressly rested on the travaux préparatoires. Legislative reforms are commented upon before they are enacted. For instance, twenty-six doctrinal studies of the reform of filiation were published in the main French law reviews, six published before enactment, and five general commentaries. ${ }^{61}$

\section{CONCLUSION}

This article originated as a comparative counterpart to Professor Richard Danner's article on the interpretive practices of U.S. courts. He persuasively argues that the greater availability of legislative information and documents generated during the legislative process led to increased use of legislative history in the early twentieth century. He looks specifically at the history of printing and distribution of Congressional documents. For a comparative perspective, this article looks at how courts use legislative materials-travaux préparatoiresin France, a civil-law jurisdiction.

The differences between the two countries are predicated on the history of their legal systems, differences in conceptual frameworks, and the respective roles of courts and legislatures. In the civil law tradition, the codes were written with broad provisions that necessarily led to interpretation by judges as they applied the principles of the

58. COUDERC, supra note 27 , at 250.

59. Id. The two official web sites of the National Assembly at http//www.assemblée-nat.fr and Senate at http//www.sénat.fr contain much useful information on legislative proposals, legislative history, and new laws, including full text documents available online.

60. COUDERC, supra note 27 , at 250.

61. Id. at 250 . 
code's articles to the circumstances of each case. The mistrust and caution that common law systems show toward the use of legislative history come from historical distrust of statute as a derogation of the common law, which in turn led to strict interpretation of statutes. Under the civil law, the trend is toward construing a statute in accordance with its spirit; under the common law, the trend is toward interpretation according to the letter of the law. ${ }^{62}$

Looking at similarities, we note that judges in both countries weigh the quality and reliability of legislative documents, as well as the extent to which there is access to them. Judges do not consider legislative history to be authoritative in the same way as a statute itself. At best, it is evidence of what the statute means. ${ }^{6}$

In France, it is hard to know what extrinsic sources a judge used to reach a decision because judicial decisions do not contain an articulation of the policy reasoning used to decide the case. It may, however, be possible to use evidence extrinsic to judicial decisions to understand how a legal system resolves policy questions. For example, very interesting and useful comparisons have been drawn from answers to a common questionnaire sent to law professors in nine different countries, including the United States and France. ${ }^{64}$ Moreover, by introducing new institutions and interpretive traditions, legal development may make these long-standing contrasts between sytems less significant. Within the European Union, the decisions of the European Court of Justice present a fascinating development, where common and civil-law traditions meet, and, in Lord Denning's terms, the interpretation of legal texts is "schematic and teleological."

62. DALE, supra note 12 , at 33 .

63. William E. Eskridge, JR., Philip P. Frickey \& Elizabeth Garrett, LEGISLATION AND STATUTORY INTERPRETATION 230 (2000).

64. D. NEIL MACCORMACK \& ROBERT S. SUMMERS, INTERPRETING STATUTES (1991).

65. Nial Fennelly, Legal Interpretation and the European Court of Justice, 20 FORDHAM INT'L L.J. 656 (1997). 